\title{
ELVEDA GÜLSARI İLE YAPRAK DÖKÜMÜ ROMANLARINDA KADINLARIN MODERNIST ALGI BAĞLAMINDA KARŞILAŞTIRILMASI
}

\author{
СОПОСТАВЛЕНИЕ ВОСПРИЯТИЯ МОДЕРНИЗМА ЖЕНЩИНСКИМ \\ ПОЛОМ В РОМАНАХ “ПРОЩАЙ ГЮЛСАРЫ" И “ЛИСТОПАД"
}

\author{
COMPARISON OF FEMALE CHARACTERS IN FAREWELL GULSARY AND \\ YAPRAK DÖKÜMÜ IN TERMS OF MODERNISM ${ }^{1}$
}

Ali Asker Ova

\section{ÖZ}

Çağdaş Kırgız edebiyatının en büyük kalemi olan Cengiz Aytmatov, Elveda Gülsarı adlı eserinde modern dünyanın yerel ve ulusal olanı niçin ve nasıl etkilediğini sorgular. Çok boyutlu değişimin yanında kimlik-benlik denklemindeki bireysellik-toplumsallıkla şekillenen kimlik kurma olgusu da Aytmatov'un ilgilendiği/işlediği konulardır. Yazar hem ideolojik, toplumsal ve kültürel değişimin bireyin iç dünyasına yansımasını hem de bireysel ve toplumsal boyutları olan kimlik kurmayı eserlerinde irdeler.

Aytmatov'un sorgulayıcı anlayışının bizim edebiyatımızdaki karşılıklarından biri de Reşat Nuri Güntekin'in Yaprak Dökümü adlı romanıdır. İki eserde de modernleşme farklı yüzleri ile işlenir. Değişime ayak uydurma, kendi özüne ve özgün niteliklerine karş1 yabancılaşma ve değişimin karşısında muhafazakar biçimde değerlerine sahip çıkma üçgeninde, roman/öykü kişilerinin hayatları her iki eserin ortak noktalarını oluşturur. Bir yanda modernleşmeye direnen ve kaybeden tipler/kişiler işlenirken, öte yanda modernleşmenin güçlü rüzgarına kendini kaptırıp yeni bir yaşam tarzı, değerleri ve algıyı oluşturan kişiler/tipler de değişim-muhafazakarlık ekseninde iki diyalektik unsur olarak kendine yer bulur. Her iki romanda da modernleşmenin bireyler üzerindeki psikolojik ve sosyo-kültürel etkileri eski-yeni ekseninde karşıtlıklar biçiminde işlenir.

Bu makalede; Cengiz Aytmatov'un Elveda Gülsarı ve Reşat Nuri Güntekin'in Yaprak Dökümü adlı romanlarındaki kadın kahramanlar modernleşme açısından karşılaştırılmıştır.

Anahtar Kelimeler: Elveda Gülsarı, Yaprak Dökümü, Kadınlar, Yabancılaşma, Modernizm

\section{АННОТАЦИЯ}

Известный представитель киргизской литературы Чингиз Айтматов в своём произведении “Прощай, Гюльсары” истолковает способы и причины воздействия современного мира на местные и национальные обычаи. Наряду с различными изменениями, формирование личности в условиях сравнения темы личность и индивидуальность, является центральной для Ч. Айтматова. Писатель изучает воздейсвие идеологии, изменений в культуре общества, водействие на внутренний

\footnotetext{
${ }^{1}$. DOI : 10.17498/kdeniz.034
} 
мир индивида и путь формирования личности с идивидуальными и общими чертами характера.

В отечественной литературе похожим на произведение Айтматова "Прощай, Гюльсары" является роман Решада Нури Гюнтекина “Листопад”. В обоих двух романах модернизм рассматривается с разних точек зрения. Общим для обеих произведений является треугольник - идти в ногу наряду с изменениями, отчуждаться от свойственных характерных черт и быть консервативным. В романах, с одной стороны, показаны консервативные, сопротивляющие модернизму персонажи, с другой стороны, персонажи, воспринявшие новый стиль и ценности жизни, т.е. в романах описываются типы двух диалектических составляющих. В обоих романах рассматриваются итоги психологического и социально-культурного воздейсвия на личность индивида и всё это исследуется в рамках противостояния старого и нового.

В статье с точки зрения модернизма, сопоставлены образ женщины в романе Чингиз Айтматова “Прощай, Гюльсары” и Решада Нури Гюнтекина “Листопад”.

Ключевые слова: “Прощай Гюльсары”, “Листопад”, женщинf, отчуждение, модернизм.

\section{Giriş}

Bir aydınlanma projesi olarak sürekli ve doğrusal bir ilerleme anlayışı üzerine oturan modernleşme; ideal toplum düzenini hedefleyen bir anlayıştır. Kapitalist toplumun ortaya çıkışına denk düşen ve sanayiye dayalı yapıya geçişin izdüşümü olan modernleşme, toplumsal açıdan belirli bir ilerleme ve uzmanlaşmayı da beraberinde getirir. Bu ilerleme, yenilikleri kapsaması, yeni ve daha uygar bir yaşam tasarımı sunması, üretimi artırması, bir kültürün hem iktisadi hem de teknolojik açıdan diğer kültürlerle /ülkelerle rekabet gücünü artırması bakımından ileri ve olumlu; diğer boyutuyla da gelenekten kopuşun, bireysel ve toplumsal değerlerin değişkenliğinin, yeni yaşam tasarısına uyum sağlayamayan bireylerin ortaya çıkışının ve toplumsal dinamiklerde çalkantılı bir dönemin habercisi olduğu için olumsuz çağrışımlara sahiptir.

Toplumun eski değerlerinden soyutlanıp yeniden tasarlanması olarak algılanan modernleşme, edebiyatın en çok ilgilendiği/işlediği konularından biridir. Hem dünya hem de Türk edebiyatında birçok türde, çeşitli yönleriyle ele alınan modernleşme en çok roman ve şiirlerde işlenir. Geleneksel, tarımsal üretim ve küçük çaplı el sanatlarına dayalı durağan bir yapıdan sanayileşmiş, şehirleşmiş, okur yazarlık oranının arttığ 1 , kitle iletişim ve ulaşım araçlarının geliştiği dinamik bir yapıya geçişi temsil eder. Edebi eserlerde hem sosyolojik hem de psikolojik etkileriyle yer bulur. Şiirlerde de kendine önemli bir yer edinen modernleşmenin, toplumsal ve kültürel alanda ne türden değişimler yarattığı, toplumu hangi boyutlarda bir varoluş biçimine yönlendirdiğinin yanında, değişim ve dönüşümün karşısında bireyin kültürel kodlarında yarattığı etki ve iç dünyasına yansıyan yıkım/bunaltı/yabancılaşma gibi izlekleri de kapsadığı unutulmamalıdır.

Modernleşmenin insanlar arası ilişkilerde yol açtığı yıkımı tanımlamak için kullanılagelmiş çeşitli kavramlar arasında en çarpıcı ve en kolay anlaşılanı "şeyleşme"dir. Modern toplumda insanın ve insana ilişkin olan her değerin yalnızca "şey" veya nesneye ait bir olgu veya sorun olarak algılanabilmesi şeyleşme olarak değerlendirilir. Günümüz insanı, kendinden uzaklaştırılan dünyanın saygı, korku veya nefret uyandıran bir dizi nesne olarak karşısına çıkmasını engelleyemez. 
Şeyleşme; tamlığın kaybolmasına yol açan bir metafor biçiminde edebiyata yansır. Bu açıdan bakıldığında Yaprak Dökümü, Türk modernleşme sürecinde toplumsal çözülmenin boyutlarını temel dinamik olan aile üzerinde irdeler. Değişimle birlikte yitirilen değerler, Ali Rıza Bey ve ailesi üzerinden yansıtılır. Romanda değişim sürecinin toplumdaki bireylere yansıması sosyal zaman unsurlarıyla birlikte değerlendirilir. Yaprak Dökümü'nde kültürel çözülmenin yanı sıra Ali Rıza Bey'in babalık otoritesini yitirmesi izleksel kurguyu belirler. Bu izlekler 1şığında toplumsal ve bireysel çözülme, Türk modernleşme sürecine eleştirel bir bakış olarak sunulur.

Bir geçmişe dönüş romanı olan Elveda Gülsarı ise Cengiz Aytmatov’un özelde Kırgız, genelde de tüm Türk dünyasının ortak kültüründen, gelenek ve göreneklerinden kesitler sunduğu; sistemi de zaman zaman eleştirdiği, hayatını yılkıcılık ve çobanlık yaparak geçiren Tanabay ile yorga Gülsarı'nın bir ömür süren hüzünlü arkadaşlıklarının hikayesidir. Aytmatov; modernleşmenin getirdiği kültür ve medeniyet değişiminin, daha doğrusu kültür - medeniyet ikiliğinin yarattı̆g kuşaklar arası anlayış farklılıkları ile sosyal çatışmanın, bireysel ve kurumsal süreçlerdeki ilişkisel ağı nasıl ve ne şekilde etkilediği anlatır. Toplumsal ve kültürel değişim karşısında özellikle kadın kahramanların tavır alış biçimleri ve sorunlarla baş edebilme stratejilerini işler.

Elveda Gülsarı'da geleneksel olanla teknoloji yan yanadır ve bu durum çeşitli buhranlara neden olur. Bu buhranlar siyasi, ekonomik ve psiko-sosyal boyutlariyla irdelenmeye çalışılır. Yaprak Dökümü'nde ise ana tema "Batılılaşmanın yanlış anlaşılması " değil, değişen sosyo-kültürel yapıdaki ikiliğin bir yandan kendini yok eden diğer yandan da karşıdakini anlamlandıran yönleridir. Her iki romanda da kadın kahramanlar üzerinden irdelenen modernleşme; aslında toplumun ve bireyin "değişim zihniyeti"nin özetidir.

$\mathrm{Bu}$ çalışmada, evrensel bir kavram olan "modernleşme"nin Kırgız kültür hayatındaki yansımalarıyla Türk kültür hayatındaki yansımalarının neler olduğunu iki roman karşılaştırılarak anlatılacaktır. Karşılaştırma, iki romandaki kadınlar üzerinden hem sosyal hem de psikolojik boyutlarıyla yapılacaktır.

\section{Modernizm}

Modernizm ileriye doğru giden bir eğilimin ifadesidir. Geleceğe yönelik yapılan yatırımların insanı daha doğru, daha iyi, daha güzel bir dünya ile buluşturacağı iddiasını taşımaktaydı. $\mathrm{Bu}$ gelecek tasarımı doğrultusunda öğrettiği kavramlar "aydınlanma", "kültürel devrim", "akıl", "mantık", "deneycilik", "bilimsellik", "ahlaklllık" ve "toplumculuk" gibi değerlerdi (Aşkaroğlu, 2015a:30). Aydınlanma hareketinin bir sonucu olan modernizm, kapitalizmle yerelden çıkarak küreselleşir. Küreselleşme sayesinde "ortak" insanlığa doğru adımlar atılır. Bilim, bilgi ve teknoloji evrensel bir dile/dizgeye dönüşür.

Bir toplumsal değerler sistemi olan modernite, XVII. yüzyılda Avrupa'da ortaya çıkar ve zamanla tüm dünyaya yayılır. Moderniteye bağlı olarak ortaya çıkan modernizm ise Avrupa'da etkisini açık bir şekilde sanayi devriminden sonra gösterir. Somut olan modernite hareketle vardır, modernizm ise sabittir ve temelde ideolojiktir. Aydınlanmanın başat öğelerinden biri olan modernizm; bilim, ahlak ve hukukun nesnel ve evrensel olması gerektiğini şiddetle savunduğu için ideolojiktir. Bu yaklaşımın bir sonucu olarak modernizm; akla, bilgiye, ilerleme ve gelişmeye duyulan inancın ifadesidir. 
İlkel insandan çağdaş insana uzanan yolda modernizmin yapı taşlarından biri de maddeye olan inançtır. Madde inancına dayanan bu ideolojinin çarklarında dönen insan, eski ile yeni arasında bocalar. İnsanın tinsel boyutunu hiçe sayan maddeci anlayışın dayatmaları insan-insan ve insan-toplum çatışmalarını da beraberinde getirir. Uygar ve insani gelişmişlik düzeyi yüksek toplumlar kurma iddiasındaki modernizm, hız kavramını da insan hayatına sokar. İnsan, hız ve zaman ikileminde zamanla değer yitimine uğrayıp hem kendine hem de ait olduğu çevreye yabancılaşır. Böylece olağan hayatından sürekli seçimlerle boğuştuğu yeni bir hayata doğru itilen birey, olağan ile yeni arasında gelişen bir çatışmanın içinde zamanla kaybolabilir.

Aklı refere ederek dünyayı değiştirmeye çalışan modernizm, dünyayı tek tipleştirir. Evrensel ilerlemeyi ön gören ve düzene uygun bir zihin talep eder. Para ve gücü elinde bulunduranların dünyaya egemen olma biçimine dönüşür.

Farklı olanın küme dışında kaldığı "yeni düzen"de, herkes benzer olmalı ve benzer yaşamalıdır. Egemenlerin "ötekileştirme" çabalarına karşı koyan bilinçli kişiler hariç, hemen herkes birbirine benzemeye başlar. Ütopik olan yeni dünya düzenine göre herhangi biri olmayı kabul etmeyen kimse, asimile edilip yok edilir. Kaos, savaş, açlık vb. kitlesel yok oluşları her zaman bir kırbaç olarak kullanan egemenler; modernizm ile tüm bu kabusların biteceğini, dünyanın daha yaşanabilir bir yer olacağını sürekli aşılamaya çalışır.

Sömürgeleştirmenin de öyküsü olan modernizm; yeni ve çağdaş köleler üretir. Onlar gibi düşünmeyenleri "vahşi, yabanıl" olarak sınıflar ve "öteki"ni evcilleştirmeye çalışır. "Efendi" ve "Köle" diyalektiği açısından bakıldığında benzer bir perspektifle karşılaşırız. İlerleme ve kalkınma "efendi"nin hayatını kolaylaştırırken zamanla "köle"nin hayatını cehenneme çevirir. Bundan dolayı modernizmin literatüre kazandırdı̆̆ 1 "ilerleme", "köle" açısından içi boş bir kavramdan öteye gidemez.

Egemenlere göre modernizm, toplum ve birey hayatının birçok alanında önemli değişiklikleri de beraberinde getirir. Ekonomi daha da düzelecek, kültür ve eğitim hayatı başkalaşıp gelişecek, politik sistemler profesyonelleşecektir. Öteki açısından, düşünen; başkaldıran açısından bu sayılanlar bir kaostan başka bir şey getirmeyecektir.

XVI. yüzyıldan XX. yüzyıla değin giderek evrilen ve evrenselleşen modernizm, çağımızda kapitalizm rüzgarını da arkasına alarak daha da canavarlaşır. İletişimin küreselleşmeyle zirveye çıktığı iletişim/bilişim çağında, modernizmin dünya tasarımı da olgunluk çağına varır: sadece nesnenin sunacağı kişisel zevkleri öneren tüketim toplumu.

XIX. yy'da; kurulan fabrikalar, gelişen sanayi bölgeleri, üretilen malların şehirlerarası ve ülkelerarası akışı, ekonomik dengelerin değişmesinin yanında birçok sosyokültürel ve ideolojik etkileşimi de beraberinde getirir. Metropoller; yeni sosyal, ekonomik ve kültürel ilişkilerin tanımlandığı, insan ve araç trafiğinin yoğun ve hızlı olduğu, giderek daha çok göç alan, hızlı ve sürekli değişim ve devinimin yuvası olur. Tüm bu değişimler; "Katı olan her şeyi buharlaştırmış" (Harvey, 1997:319) ve eski kavram ve değerlerin yerine, modernliğin gereği olan yenilerini getirmiştir. Bireysellik, öznellik, parçalanma, belirsizlik ve çoğulluk modern hayatın yeni kavramları haline gelmiştir.

Birçok kavramı silik gölgeler haline getiren modernizm, kendi kültürünü oluşturur. Toplum ve birey bu kültüre göre yeniden şekillendirilir. Modern hayatın kölesi olan birey; uyum sağlama çabasında mücadele, çelişki, parçalanma, yenilenme ve belirsizlik akıntısında sürüklenir. Modern hayat; hem yereli hem de bireyi kendi değirmeninde ögütür, un ufak eder ve başkalaştırır. Özne konumundaki bireyden nesne konumundaki bireye geçişte birtakım sancılar yaşansa da nihayetinde kazanan modernizm olur. Modernizme 
yönelen sorgu ve şüphenin göçmen kuşların kanadında uzaklara kovulduğu bu yeni dünya düzeninde sanayileşme, makina, üretim, daima üretim, daima ilerleme vb. kavramlar işlene işlene birey de belirli bir kıvama getirilir ve artık sorgulama yetisini ya da iradesini/arzusunu yitirir. Çok üretip çok kazanınca çok mutlu olmayı vadeden aydınlanmacı akı1, başkalarının mutsuzluğunu önemsemez. Çünkü "ötekiler", belirlenen ihtiyaçlar peşinde koşarak ömrünü tüketen şeylerdir.

Modernizm; tarıma dayalı ekonomik yapıdan sanayiye ve uzmanlaşmaya yelken açan ekonomilere geçişte önce insanı ve insanın hayata bakış açısını değiştirir. İnsan-Tanrı ilişkisini olağan seyrinden koparır ve yepyeni bir maceraya sürükler. Koşulsuz ve sorgusuz itaat anlayışından kopan birey, Tanrı'nın yerine artık başka şeyleri de koymaya başlar. Özgürlük, eşitlik, adalet, hukuk vb. artık yeni dünyanın başat kavramlardır. Tanrı iradesi yerine insan iradesi belirginleşir. Çünkü tanrı otoritesi aklın önünde ciddi bir engeldir ve bu engelden kurtulmak gerekir. $\mathrm{Bu}$ bağlamda otorite kaybolmaz, sadece Tanrı'dan rasyonalizme doğru yer değiştirir.

Yeni dünyada artık bireysel kahramanlıklar ve özveri yoktur, akıllı davranıp çıkarını korumaya çalışma, çıkarlar ölçeğinde plan ve program vardır; "günümüz insanının damarlarındaki kahramanlık eğilimini bilim, bilimsel gelişmeler ve teknolojik imkanlar emip boşaltmıştır; ya da yaşamın karşısında kahramanca bir duruş sergileyerek kendini kitle adına feda etmenin yüce erdem ve anlamı modern insanın "sağırlığı", "körlüğü", "kayıtsızlığı" ve "kendine dönüklüğü" yüzünden artık yitmiştir," (Aşkaroğlu, 2012:156). Aydınlanma ve modernizmle birlikte insan da yeniden oluşturulur. Doğaldan mekaniğe devinen bir yaşam söz konusudur artık; mekanik şehirlere ve insanlara geçilir. Modernizm sadece şehri değil, birey ve aileyi de biçimlendirir ve yönetir.

Modernist akıl açısından bilgi, klasik anlayışın aksine bilgelik değildir. Bilgi, doğayı keşfetme konusunda/çabasında sadece bir araçtır. Teknoloji de bilginin özüdür. Bilgi, nesneye egemen olmaya yarayan teknolojinin araçlarından birine dönüşür. $\mathrm{Bu}$ nedenle modernizm; sadece dış dünyayı düzenlemekle, planlamakla kalmaz; insanın iç doğasını da düzenler. Sadece dış dünya değil, insanın iç dünyası da yavaşça köleleştirir. Geçmişe ait ne varsa yok edilmelidir çünkü geçmişten kopmadan geleceğe ulaşmak olanaksızdır.

Ekonomik gelişme ve kentsel yaşam, toplumsal rollerin ve sorumlukların çoğalmasına ve beraberinde de kimlik problemlerine neden olur. Farklı sosyal rollere kendini adapte ederek toplumsal rolleri ve sorumlulukları arasında bölünen modern birey, iç gerilim ve çatışmalar yaşar. Dolayısıyla modern yaşamın toplumsal koşulları bireyi tercihleri ve seçimleri konusunda zor durumda bırakır. Geleneksel toplumlarda kimlik oluşumu, üzerinde fazla tartışılmayan bir kavramken modernizmle birlikte kimlik hareketli, çoklu, bireysel, öz - dönüşümsel, ve değişime ve yeniliğe açık hale gelmiştir (Kellner, 2001:195 - 196).

Modernizm öncesi dönemde her şey Tanrı'nın birliği temelinde açıklanmaya çalışılırken, modern dönemde Tanrı'nın yerini birey alır, birey odaklı bir düşünce biçimi hakim olur. Bu gelişmelere paralel olarak çözülmeye başlayan geleneksel kurumlar -din gibi - toplumdaki etkisini yitirmeye başlar ve bu kavramların yerini akılcılık alır. Modernizmde toplumsal rol ve normlarla biçimlenen kimlik, sınırlı olarak tamamlanmış ve ait olunan bir şey olmaktan çıkmıştır. Modernleşmeyle birlikte kimlik bunalımına giren birey, yaşamın anlamını geçmişte arar ve "ben kimim?” sorusunu sorar. 


\section{Modernist Kültür}

Modernist roman; gerçeklik karşısında tedirgin olan, iç dünyasına çekilen, ona yabancılaşan ya da sorgulayıcı bir tutum geliştirerek acze düşen 'birey'i işler ki bu birey yalınlığını yitirerek parçalanan gerçeklik ve bu gerçekliğin karşısında kimlik ve kişilik bunalımına girerek kendine güvenini yitiren bir tiptir. Modern dünyaya, modern dünyanın olgularına yenilmiş; bunların etkisiyle pasifleşmiş, iç dünyasına çekilmiş biridir 0 . Geleneksel-gerçekçi romanın kahramanı gibi genellikle dış dünya unsurlarıyla didişen, eylem içinde olan figür değil; edilgenleşmiş, iç gerçekliğiyle ön plana çıkmış 'başkişi'dir. Dolayısıyla, figürün modern dünya karşısında içine girdiği bu durum, onun bu dünyaya duyduğu tepkinin sonucu ortaya çıkmıştır, denilebilir. O, modern yaşama ayak uyduramamakta ve bunu tepkiye dönüştürüp iç dünyasına yönelmektedir.

\section{Kadın ve Toplum}

Tarihsel olarak kadının erkek karşısında ağırlığını yitirmesi ekonomik temellere dayanır. Erkek egemen toplumun ve ataerkil aile modelinin kökleri, avcılık ve toplayıcılıktan tarım ekonomisine geçiş sürecinde yatar. İnsanlık tarihinin ilk büyük devrimi olan tarım devrimi büyük olasılıkla kadının bir eseridir. Bununla birlikte tarıma geçiş, kadının sosyo-ekonomik statüsünü kaybetmesinin de başlıca nedenidir. Ekonomik etkinliğin fizik güç kullanımına dayandığ 1 tarım toplumunda, fiziksel olarak kadından daha güçlü olması, erkeği ön plana çıkarmıştır (Şenel, 2004:15-24).

İslâm öncesi Türk toplumunda erkekle hemen hemen eşit haklara sahip olan kadın profili ile karşılaşılır. Ülke yönetiminde "Hatun"un "Hakan" ile eşit söz hakkına sahip olması, savaşlarda kadın Alp tipi ile karşılaşılması dikkat çekicidir. İslamiyet'ten önceki Türk kavimlerinde ata binip kılıç kuşanan Türk kadını, İslamiyet'in Türkler tarafından kabulünden sonra meydanlardan çıkar ve zamanını evde geçirir. Türkler artık yerleşik hayat geçmiştir ve İslam'ın "cihat" kavramı yalnızca erkeklere özgüdür. Yeni dinle birlikte geleneksel kültür öğelerinin yerini semavi insanlar alır.

Kadına biçilen rolün değişmesiyle birlikte kadının sosyo-kültürel hayattaki konumu da değişir. Mekansal açıdan dıştan içe yani eve doğru yüzyıllar boyunca akan Türk kadını, Türkiye'de Cumhuriyet'in ilanıyla Kırgızistan'da ise Sovyetler Birliği'nin dağılmasıyla birlikte yeniden gün yüzüne çıkar, sokaklara iner, sesini duyurur.

\section{Yaprak Dökümü ve Elveda Gülsarı'daki Kadınların Modernleşme Açısından Karşılaştırılması}

Yaprak Dökümü'nde Reşat Nuri'nin, Ali Rıza Bey aracılığıyla erkeğin cinsel kimliğini vurgulaması dikkat çekicidir. Bunun ilk göze çarpan nedeni, erkeğin, değerleri belirlenmiş bir toplumun içinde, koruyucu ve sürdürücü etkisidir. Ali Rıza Bey, toplumun kalıcı değerlerini ve statükoyu belirler. Yeniliğe karşı olmasa da yeniliğin sadece bir değişim biçiminde ortaya çıkışına karşı durur. Onun penceresinden bakıldığında, asıl meselenin değişimin olması değil, bunun nasıl gerçekleşeceğidir. Başka bir ifade ile, o toplumun hızlı değişimin yaratabileceği travmatik etkilenimlerin karşısında duran denge unsurudur. Değişimi/dönüşümü frenleyendir, engelleyen değil. Bunu da öncül nesillerden (anne ve babasından) öğrenmiş olduğu yaşam tasarımı ile gerçekleştirmek ister.

Yaprak Dökümü'nde, erkeğin öncelikli konumuna göre betimlenen kadın figürü, ilk bakışta ataerkil bir toplumun değerleri ile hemen "kirlenmeye" uygun biri olarak sunulur. $\mathrm{Bu}$ açıdan o hep korunup kollanmalıdır. Aslında, kadının rolü, Güntekin tarafından ikincil olmaktan ziyade, tüketim toplumunun yavaşça ortaya çıkışı ile birlikte, köklerden ve geleneklerden daha az beslenmiş bir birey olarak, kadının yeni olgular ve sosyal hayatta 
savrulmaya daha fazla uygun olmasıdır. Yazarın devamlı "baba, ata" rolündeki Ali Rıza Bey'den yana tavır alması, ilk bakışta "ataerkil" bakış açısının yansıması gibi görünse de toplumsal değişimin denge unsuru olan erkeğe daha fazla sorumluluk yüklemek anlamına gelir.

Elveda Gülsarı'da durum farklıdır. Aytmatov her ne kadar "ataerkil" anlayışa saygı duysa da tavrını kadından, "ana"dan yana koyar. Reşat Nuri açısından, yeni özgürlük alanının açılması ile birlikte, kadınlar ne ölçüde hızlı ve dengesiz bir dönüşüme uygun olsalar da Aytmatov açısından romanın kurgulandığı zamanın itaatkar ve özünü yitiren bireylerinin değişim göstermesi o ölçüde değerlidir. Burada asıl sorun, ne Aytmatov ne de Güntekin'in evrensel geçerliliğe sahip kadın-erkek konumlandırmaları değildir. Daha önemlisi, kadının sosyal, siyasal ve kültürel boyutlarda öne çıkarılan özellikleridir. Bu açıdan, asıl dönüştürücü rol kadınlara verilmiştir. Öte yandan, modernleşme karşısında, daha önceki dönemlerde bireyselliği ve kimliği inkar edilmiş kadınların, yeni ortaya çıkan özgürlükçü bir ortamda kimlik ve kişilik kurgusu, bu konuda öncül örneklerle beslenmemiş kadınlar için büyük bir sınavdır ve oldukça tehlikeli boyutları içinde barındırır.

Güntekin'in Yaprak Dökümü romanında, kadınlar yerine erkeklere daha öncelik vermesi ile Aytmatov'un Elveda Gülsarı romanında zaten özünü çoktan yitirmiş erkeklerden çok, kadınlardan medet umması, romanların zaman ve mekan kurguları göz önüne alındığında bir taraf tutmaktan çok bir kültürel, tarihi zorunluluk olarak karşımıza çıkar.

Elveda Gülsarı'da, kadın doğurgan özellikleri ile kimlik kurucu ocaktır. Bir okuldur ve temel eğitimin ana kaynağıdır. Erkek ise çoktan şekillenmiş ve sisteme ayak uydurmuştur. Öze dönüş açısından, Kırgız insanının kültürel kodları, bu yüzden sadece kadının yaratıcı/öğretici konumunda barınır. Bu kodların, tekrar bireylere aşılanması ve gelecek tasarımının kurulması, ancak kadın ve anne figürünün oluşturduğu ve hala tütmekte olan ocak kültü ile mümkündür. Yaprak Dökümü'nde ise, toplumsal kaygılardan çok, kültürel kimliğin birey düzleminde kurulması ön plandadır. Yeni özgürlük alanı, toplumsallaşmanın erken aşamalarındaki kadın ve erkek için eşit derecede tehlike içerir. Ancak, Güntekin cinsel kimlikten ziyade, yeni yaşam tasarımında, kadınların özgürlük kavramına sorgusuz bir biçimde nesne örüntülü algılarıyla çabucak kucak açmalarını eleştirir. Her iki romanda da olumlu ve olumsuz olarak betimlenen kadın ve erkek figürlerinin entrik kurgudaki rolleri, gerçekçi birer roman olmaları açısından önemli ve uygun seçimlerdir.

Yaprak Dökümü'nün kadın kahramanları Hayriye Hanım, Fikret, Necla ve Layla'dır. Elveda Gülsarı'daki belirgin kadın kahramanlar, izleksel kurgunun akışına uygun olarak seçilmiş olan Bibican ve Caydar'dır. İki kahraman da norm karakterdir. Romandaki fon kadın karakterler ise Tanabay'ın gelini ve Tanabay'la Caydar'a yardım eden işçi kadınlardır. Kolhoz'un tayin ettiği bu işçi kadınlar; sahneyi belli belirsiz dolduran ve kanı, canı ya da düşüncesi dahi olmayan tiplerdir.

Aytmatov, roman boyunca kadın kahramanların "anne" yönlerini vurgulayarak savaşın yıkımına karşın "anne"nin bir arada tutma gücüne göndermeler yapar. Elveda Gülsarı'da "anne"ye yüklenen anlam şöyledir; "Ev-anne-yuva izleğiyle bağlantılı mutsuzluk öyküsü, Tanabay'ın yatılı okuldan geldiğinde annesini kisa bir süre evde bulamayan oğlu ile daha gerçekçi bir boyuta taşınır; Caydar yokken ocaktaki ateş bile alevsiz, korsuz bir yetim gibi kallyordu. (...) Babaları, baba idi ama analarının yerini tutamazdı" (Korkmaz 2014: 156). 
Reşat Nuri'nin betimlediği aile kurumunda ise anne figürü olumsuz birisidir. Ancak yine de, anne kavramı ile olmasa da, Fikret vasıtasıyla Güntekin, kadının birleştirici potansiyelini bir olasılık olarak okura sunar.

Elveda Gülsarı'nın başkahramanı "Tanabay"ın eşi olan Caydar; Orta Asya geleneklerine bağlı olarak yaratılan bir tiptir. $O$ bir annedir ve anne evin direğidir. Ev, anne -Caydar- sayesinde bir aradadır. Özelde Tanabay'ın evini, genelde de tüm bozkırı ayakta tutan anne -Caydar-, dimdik duruşuyla bir ülkünün, ulusun direğidir aslında. Tanabay kadar olmasa da etkin bir şekilde çalışır, koyunlara bakar ve onca işine rağmen çocuklarına analık eder; “ Ertesi gün anaları dönüp gelince nasıl sevindiler, nasıl! Ikisi iki taraftan analarının boynuna sarllmış, bırakmıyorlardı. Zor ayrlldılar annelerinin boynundan. Babaları baba idi, ama analarının yerini tutamazdl" (Elveda Gülsar1, 2004:128). Roman boyunca ideal kadın tipinin tüm özelliklerini kendinde toplayan, olgun, sağlıklı düşünebilen biri olan Caydar, soğukkanlı ve anaç özellikleriyle okuru adeta büyüler. Onun asıl kurucu ve birleştirici gücü sadece bir görev kadını olmasında değil, çocuklarına ihtiyaç duydukları sevgi ve ilgiyi göstermesinde yatar. Çocuklarına yaklaşımı, dünyayı nesnenin ve tüketimin boyunduruğundan kurtaracak olan şefkat ve koruyuculuk üzerine kuruludur. $\mathrm{O}$, maddenin doyurduğu beden yerine, tinsel gereksinimlerin doyurabileceği yüreğe ve bilince hitap eder. $\mathrm{Bu}$ bakımdan Caydar, tinsel ve kültürel doğurganlığın simgesine dönüşür. Öte yandan, modernleşmenin karşısında, Caydar'la bağdaştırılabilecek olan Ali Rıza Bey, sürekli çalışmak zorunda oluşu yüzünden, çocuklarına maddi katkılar sağlasa da ruhsal doygunluğu onlara sunamaz. Bunun sonucunda, gereksinim duydukları sevgi ve şefkati yeterince doyuramayan çocukları, bu değerler yerine modern toplumsal yaşamın sunduğu tüketime ve maddi doygunluğa yönelir. Çürüme ya da yozlaşmanın arka planında yatan gerçeklik, psikolojik gereksinimlerden/olgulardan bağımsız bir biçimde gerçekleşmez. Bu açıdan, tinsel doygunluğu sağlayan Caydar çocuklarını eğitme ve yönlendirme konusunda başarılı olurken, ilk planda maddi doygunluğu sağlamaya yönelen (zorunluluklardan dolayı da kısmen ihmalkar davranan) Ali Rıza Bey bütünleştirici rolünde başarısız olur.

Aytmatov'un ideal kadın tipi olarak sunduğu Caydar, "annelik"le yazar tarafından ödüllendirilir. Yaprak Dökümü̈'nde Caydar'la benzer nitelikler taşıyan tek kahraman Fikret'tir. Ali Rıza Bey'in büyük kızı olan Fikret; daha 19 yaşında olmasına rağmen bilgece fikirleri ve entelektüel duruşuyla Caydar'ı hatırlatır. Hem Fikret hem de Caydar fiziksel açıdan güzel olmasalar da inançlı, ağırbaşlı, bilgili ve prensipli oluşlarıyla okuyucu etkiler. İki kadının da ahlak anlayışı birbirleri ile örtüşür. Her ikisi, toplumsal dinamiklerin ve değişimlerin farkındaki bireyler olarak, kendilik değerlerini kurmayı başarırlar. Çevrelerine etki etmek adına uzun ve yorucu uğraşlara girerler. Ancak onların düşünsel boyutundan daha çok, duygusal varoluşları insan merkezlidir ve onları ideal kılan da duygusal ve kültürel boyutlarıdır. Caydar, çocuklarına yönelik bir tür toplumsal rol üstlenirken, Fikret de kardeşlerine yönelik yapıcı bir kimlik içindedir. Caydar, belki de annelik konumu ve koşulsuz sevgi sunumunun yanısıra, toplumu yeterince gözlemleyebilecek yaş olgunlukta olması sayesinde, başarılı olur. Fikret ise, her ne kadar olgun bir kadın gibi davransa da, her şeyden önce koşulsuz sevgi sunabilecek gerekçesi yoktur ve bu yüzden sonuna kadar savaşmak yerine daha kırılgan bir direnç gösterir. Üstelik, Fikret, toplumdan haberdar olsa da yaşının küçük olması onu toplumsal dinamiklerin karşısında daha da güçsüz kılar. Bu yüzden, Aytmatov'un Caydar'a yüklediği bütünleştirici rolü tam anlamı ile gerçekleştirme olasılığına sahip değildir.

Elveda Gülsarı'nın kutsadığı "anne" motifi Yaprak Dökümü'ndeki Hayriye Hanım'dan çok uzaktır. Hayriye Hanım duruşu, hayatı algılayışı ve birikimi ile bir anne 
olmaktan çok yeniyetme bir genç kız gibidir. Aslında, modernleşme öncesi toplumun tümü ile ataerkil bir yapıya sahip olduğu düşünüldüğünde, Hayriye Hanım'ın Caydar gibi bütünleştirici, sorunları çözen, yol gösterici bir figür olması beklenemez. Kadını, bir ev kadını olarak toplumdan ve toplumsal gerçeklerden, üretimden ya da etkin bir özne konumundan alıkoyan ataerkil düşünce, onu sadece kocasına hizmet eden, evi derleyip toplayan edilgen bir nesne konumuna indirger. Ev dışında, Hayriye Hanım herhangi bir toplumsal rol üstlenmez, çalışmaz ve toplumsal değişimin pek de farkına varmaz. Bir bakıma, dış dünyanın kendi çocukları için ne türlü tehlikeleri barındırdığının farkında değildir. Zaten oldukça otoriter olan kocasının gölgesinde kadınlığını yaşayan, kimliğini kocasının mesleğine ve konumuna göre kazanan birisidir. Bu özellikleri ile çocuklarını yetiştirmiş ve onları dış dünyanın gerçeklerine/tehlikelerine karşı bir bakıma yeterince donatamamıştır. Elveda Gülsarı'da Caydar, annelik dışında bir işe sahiptir ve hayatın sorumluluklarını doğrudan deneyimleyen birisidir. Hayriye Hanım'a göre, toplumu daha yakından gözlemleyebilen konumdadır ve kocasına göre değil, kendine göre bir kimliğe ve benliğe sahiptir. Bir bakıma Hayriye Hanım kendisini ve toplumu başkasının aynasından seyrederken, Caydar kendi yüzünü ve toplumu birinci elden tanıma olanağına sahiptir. Birinci konumda bulunan Hayriye Hanım'ın, çocukları büyüdüğünde onları denetlemek, yönlendirmek ve korumak yerine, onların iradeleri doğrultusunda ilerlemesi, hayatı boyunca zorlandığı edilgenlikle örtüşür. Öte yandan, hayatın tüm sorumluluğunu üzerine alan Caydar gibi bir kadının da, hayatın öznesi olması onun kurucu/yapıcı bir kimlikte varoluşunu ortaya çıkarır.

Elveda Gülsarı'nın bir diğer önemli kadın kahramanı olan Bibican, Caydar'ın aksine kayda değer bir toplumsal rol üstlenmez. Konumu gereği hayatın çok boyutlu sorumluluklarından uzaktır. Çocuk sahibi olmayışı bu çok boyutluluk zincirini kıran temel nedendir. Madde-tinsel gereksinim bağlamında düşünüldüğünde kayda değer bir simge olmayan Bibican, Caydar'a nazaran çok daha edilgendir. Yaprak Dökümü'ndeki Ferhunde de çok boyutlu sorumluluk açısından Bibican gibidir. O da kurucu/yapıcı bir kimliğe sahip değildir. Sosyokültürel açıdan "eş, gelin" profili ile karşımıza çıkan Ferhunde, bireysel bir kimliktir. Yazar, bu bireyselliği entelektüel altyapısı olan, düşünceleri yüzünden benzerleri arasından sıyrılan pozitif bir bireysellik olarak betimlemez. Ferhunde'nin bireyselliği daha çok tüketen, maddeci, kültürel kökleri olmayan bir bireyselliktir. Reşat Nuri; kocası Şevket'le kayınpederi Ali Rıza Bey arasında çok yönlü bir çatışma yaşayan Ferhunde'den ev hanımlığı dışında hayata somut katkı beklemez. Ali Rıza Bey'in ev hanımlığı rolünü dahi yerine getirmediğini düşündüğü Ferhunde, otoriter ancak sorunlu biri olarak resmedilir.

Yaprak Dökümü'nde modern hayatın muzır, onaylanmayan tüm yönleri roman boyunca kadın karakterler üzerinden verilmeye çalışılır. Yazarın sözcüsü konumundaki Ali Rıza Bey'e göre -romanın norm karakterlerinden olan- Şevket'in yitip giden hayatının da baş sorumlusu Ferhunde'dir. Yazar, Şevket üzerinden dejenere olan erkek tipini verirken modern kadına da atıfta bulunur ve edilgen-maddeci modern kadının sakıncalı olduğu kanısına varır. Modern hayatın geleneksel ile çatıştığı bu noktada, sokağa yeni yeni çıkan kadın profilini temsil eden Ferhunde, her ne kadar Ali Rıza Bey için sakıncalı olsa da yeni hayatın bir simgesidir ve bu simge Tanzimat'tan bu yana süregelen savaşı kazanan ve artık yüzünü tamamen Batı'ya dönen yeni İstanbul'un sosyokültürel değişimini sembolize etmesi bakımından önemlidir. Elveda Gülsarı'da durum biraz daha farklıdır. İşte, sokakta, bozkırda var gücüyle çalışan kadın tipleriyle karşılaşırız. Her ne kadar Bibican, bu sayılanlar için pasif bir konumda betimlenmiş olsa da onun romandaki özgül ağırlığı ile Ferhunde'nin Yaprak Dökümü'ndeki özgül ağırlığı arasında çok fark vardır. Ferhunde, modern İstanbul kadınının birkaç boyutunu tam manasıyla temsil ederken Bibican, klasik 
Kırgız kadınını tam manasıyla temsil etmez. Tüketici konumda olan Ferhunde ve Bibican'ın modern hayattan algıladıkları da etkilenme dereceleri de farklıdır. İki kadın da toplumsal açıdan ikincil konumdadır. Ferhunde ataerkil toplum yapısının kurbanı olduğu için ikincil konumdayken Bibican, üretken olmayışı yüzünden ikincil konumdadır. Özellikle Reşat Nuri, bu ikincil konumun doğal sonucu olarak Ferhunde'nin modernizmi yanlış anlayıp yanlış yaşadığı sonucuna varır.

Yaprak Dökümü'nde Ferhunde'nin eve karşı düşmanlığı, evi sürekli kapalı mekan olarak algılayışı ile Bibican'ın evde oluşu, evden kopamayışı da dikkat çekicidir. Ferhunde için "hayat" evin dışında, başka hayatlar ve insanlardadır. Bibican içinse ev, korunaklı ve mahrem bir alandır. Değişen toplumsal ve bireysel algılara uygun olarak yeni İstanbul'da artık ev değil, dışarısı varlık alanıdır ve Ferhunde dışarıda var olmaktadır. Engin Kırgız bozkırlarında geçen hayatının sıradanlığı içinde Bibican için dışarısı kendi yaşamı gibi durağan ve sıkıcıdır. Bu yüzden sosyalleşmeyi istemez, üretime katılmaz.

Elveda Gülsarı'da Bibican ne ölçüde içe kapanık, sakin hatta utangaç biri olarak betimlenmişse Yaprak Dökümü'nde Ferhunde o ölçüde atak, sosyal, otoriter ve içten pazarlıklı olarak betimlenmiştir. Cengiz Aytmatov Bibican'ı şatafat, lüks hayat ve eğlenceye uzak, kaderini kabullenmiş bir tip olarak sunarken; Reşat Nuri, hem çevresel hem de ekonomik koşulları bambaşka olan Ferhunde'yi kaderci olmayan, alafranga tutkunu, lüks hayat meraklısı, sonradan görme bir tip olarak sunar.

Elveda Gülsarı'da Tanabay'ı evden kovan gelin, modernizmle şekillenen çağdaş şehir hayatının hemen hemen tüm olumsuz niteliklerini üstünde toplar. Modernizmle tanışıklığına değinilmeyen ve birkaç cümlede betimlenen gelin, köyden kente göçün yıllar sonra ortaya çıkardığı "yeni, modern ve birey" olan insanı temsil eder. Tanabay'ın dünyasında soğuk, değer yitimine uğramış, bencil ve saygısız olması bakımından Yaprak Dökümü'ndeki Ferhunde'ye benzer.

Ali Rıza Bey'in düşünceleriyle Tanabay'ın düşünceleri "gelinler" için örtüşür. Ataerkil otoriteyi temsil eden her iki kahraman açısından da gelin alışılagelmiş algının dışında, otoriteyi hiçe sayan sakıncalı varlıktır. Tanabay'ın gelini ile konuşmadan evden ayrılmasıyla Ali Rıza Bey'in uzun bir süre geliniyle aynı evde yaşaması arasında bir paradoks söz konusudur. Baba-ata, otorite olan Ali Rıza Bey-Tanabay ikilisine karşı modern, şehirli ve yeni olan Ferhunde-Gelin ikilisi karşımıza çıkar. Ata-erkil ile modernşehirlinin mücadelesinde roman yazarlarının "geleneksel" olandan yana tavır alışları da dikkate değer bir noktadır.

Yaprak Dökümü'nde şehirli modern kültürün esas etkilediği kuşağın temsilcileri olarak Leyla ve Necla karşımıza çıkar. Olay örgüsünün kurgulanışı ile Leyla ve Necla'nın temsil ettiği değerler arasında sıkı bir bağ vardır. Reşat Nuri'nin şımarık, ne oldum delisi olarak betimlediği iki kızın kaderleri Ferhunde ile değişir. Ferhunde ile modernizmde yolları kesişen Leyla ve Necla, romanın çoğu yerinde "ata-baba-otorite" olan Ali Rıza Bey ile mücadele eder. Bu mücadele simgeseldir. Aslında 16. yüzyıl sonlarında başlayan ve Cumhuriyet Türkiye'sine değin devam eden Doğu-Batı, geleneksel-modern çatışmasını somutlaştırdığı tiplerle irdeleyen Reşat Nuri; tavrını geleneksel olandan yana koyarak "yanlış Batılılaşan" her kesimi Ferhunde, Leyla ya da Necla üzerinden eleştirir. Elveda Gülsarı'da "yanlış Batılılaşma" söz konusu değildir. Aytmatov, Tanabay'ın gelini üzerinden "kayınpeder-ata-otorite" düşmanlığını dile getirir. Bu düşmanlık Yaprak Dökümü'nde "baba"ya döner. Çünkü onlar "ataerkil"i ve geleneği temsil eder. 
Yaprak Dökümü'nde Leyla ve Necla'nın evlilikle ilgili tutum ve tercihleri de paranın en büyük güç olarak görülmeye başlandığının göstergesidir. Evliliğe ilişkin değerler, paranın yöneliminde değişmekte, genç kızlar evlilik kurumunun temelini aşk, sevgi gibi duygulardan ziyade zenginliğin üzerine kurmaktadır. Ailede Leyla ile Necla arasında görülen en şiddetli kavga bundan dolayıdır (Erdoğan 2005: 23). Elveda Gülsarı'daki hiçbir kadın böyle düşünmez. Evliliğe atfedilen anlam Leyla ve Necla'nın bakış açısından çok farklıdır. Maddeyle kuşatılmış bir biçimde betimlenen Leyla ve Necla'nın aksine Caydar, kol emeğine dayanan işlerde çalışmakta ve içinde bulunduğu koşullardan şikayet etmemektedir. Caydar'a göre her şey "Kolhoz"undur ve bu durum böyle de devam edecektir. Kolhoz'la kavga etmek hem mantıksızca bir iştir hem de sakıncalı sonuçlar doğurabilir. Olanla yetinip daha sıkı çalışmak gerekmektedir. Oysa Yaprak Dökümü'ndeki Leyla ile Necla böyle düşünmez. Onların konforlu hayat hayalleri ailenin parçalanmasına yol açar. Yanlış evliliklerinin altında yatan temel neden de budur. Üretim, zihinsel ya da kol gücüne dayalı hiçbir faaliyet Ali Rıza Bey'in kızlarını ilgilendirmez. Bu kayıtsızlığın altında yatan nedenlerin başında Ali Rıza Bey'in otoriter-ataerkil baba algısı yatmaktadır. Üretime, hayata katılan kızlar yetiştirmektense eşi Hayriye Hanım gibi edilgen, içe dönük kızları olmasını ister. Bu istekle çağın değişen koşulları arasındaki uyuşmazlık Leyla ile Necla'nın romanının akışındaki kırılmaların asıl nedenidir.

Yaprak Dökümü'nde Ali Rıza Bey'in gelini ve kızları (Fikret hariç) insanın kutsallığını asla önemsemedikleri gibi devamlı geleneksel yaşamın tüm değerleriyle kavga eder. Bu kavgada kadın kahramanlar- Fikret hariç - Ali Rıza Bey'i sürekli üzer, yorar ve hırpalar. Modernizme karşı son derece uyumlu olan bu kahramanlar, geleneksel olana karş1 son derece atak hatta militarist bir tutum içinde betimlenir.

Elveda Gülsarı'da Tanabay için zaman zaman cehennem olan sonsuz bozkırlar, evin direği Caydar'la yumuşar, dinginleşir. Tanabay'ın duygu dünyasında-Caydar'dan ötürü- her zaman açık mekan olan ev; Yaprak Dökümü'nde Ali Rıza Bey açısından - gelini, kızları ve eşi yüzünden- kapalı mekandır.

Elveda Gülsarı'da Kırgız bozkırlarına modernizm henüz ulaşmamıştır. Bu durum Yaprak Dökümü'nde tam tersidir Modernizm İstanbul'a ne ölçüde yakınsa Kırgız bozkırlarına bir o kadar uzaktır. Dolayısıyla kadim değerleri temsil eden Caydar'la, pek de içselleştirilemeyen yeniyi temsil eden Leyla, Necla ya da Ferhunde arasında büyük farklar vardir.

\section{Sonuç}

Kırgız halkının Elveda Gülsarı'da üretmeden tüketen, lükse düşkün, Batı'nın eğlence anlayışını kendine şiar edinmiş aile fertlerinin içine düştüğü durumu, konak hayatından apartman hayatına geçişte ortaya çıkan değer yargılarından uzaklaşmayı anlatan Yaprak Dökümü'nde bireyi geliştirip dönüştüren aile çok önemlidir. Var oluşun temeli olan aile, birincil ihtiyaçları karşıladığı gibi ikincil ihtiyaçların da karşılanması için bireyi yaşama hazırlar. Toplumdaki diğer kurumlarla da iş birliği içinde olan ailenin ana öğeleri anne ve babadır. Bir başka ifade ile, kurumsal olan kişilik kazanımının ilk örneği kadın ile erkek arasında kurulan aile birimi ile gerçekleştirilir. Her iki yazar da kadın ve erkek kahramanları birer birey olarak bize sunarken bir tarafı tutma, ona daha bir şefkat gösterme eğilimindedir. Reşat Nuri erkek-baba yanlısıyken, Aytmatov ana-kadın yanlısıdır.

Kadın imgesinin sunumu sadece bireysel düzlemde bir betimleme değildir. Hem Güntekin hem de Aytmatov, kadını toplumun temel dinamiği olarak görür. Kadın; romanlarda, yaşamın değerlerini kimi zaman olumlu kimi zaman da olumsuz biçimde, 
belirleyen/kuran asıl güçtür. Doğurgan/yaratıcı potansiyeli ile, yeni neslin varoluş mücadelesinde ve toplumsallaşma sürecinde, yaptığı seçimlerle olumlu ya da olumsuz dünyanın belirleyicisidir. Bu yüzden, kendilik değerlerini kurmanın yanı sıra, kadın bir pusula figürdür. Onun olumsuzluğu toplumsal çöküntüye neden olurken, olumlu özellikleri bir toplumun ve onu oluşturan bireylerin yaşam tasarımının da aydınlık imgesine dönüşümünü sağlar. Erkek figürü ise, her iki yazar tarafindan, toplumsal konumlamanın ortaya çıkışından sonra etkin hale gelecek koruyucu ve sürdürücü özellikleri ile betimlenir. Erkek, kurucu güç olmaktan çok, kurulan değerlerin hem taşıyıcısı hem de aktarıcısıdır. Bu özellikleri ile, kadından daha sonra gelir.

Özelde Kırgız, genelde de tüm Türk dünyasının yapısal ve kültürel değişimlerinin yansımalarını içeren romanlarıyla son asır edebiyatına damga vuran Aytmatov da Osmanlı'dan Türkiye'ye uzanan yolda, sosyal ve kültürel değişimin temellerini sarstığ 1 ilk kurum olan "aile"yi sıkça eserlerinde işleyen Reşat Nuri Güntekin gibi değişimi arzu edilen nesne olarak görür. Ancak bu değişim gerçekleşirken kendi özünü kaybeden ve giderek köklerinden kopan toplumlarının asıl kaynağa/aile ocağına ve kültürlerine yeniden dönmeleri gerektiğini de vurgular.

\section{Kaynakça}

ALTINDAL, Aytunç. (1991). Türkiye’de Kadın. İstanbul: Anahtar Kitaplar Yayınevi.

ANIK, Cengiz, SONCU, Ayşegül. (2011). "Kültür, Medeniyet ve Modernizm Üzerine 'Yaprak Dökümü' Bağlamında Bir Değerlendirme", Yeditepe Üniversitesi Global Media Journal, Bahar Sayıs1.

ASLAN, Seyfettin, YILMAZ, Abdullah. (2008). "Modernizme Bir Başkaldırı Projesi Olarak Postmodernizm", C. Ü. İktisadi ve İdari Bilimler Dergisi, Cilt 2, Say1 2.

ASSMANN Jan. (2001). Kültürel Bellek. (Çev. Ayşe Tekin). İstanbul: Ayrıntı Yayınları.

AŞKAROĞLU, Vedi. (2015a). Postmodernizm Sınırsız Özgürlük Mü? Özgürlüğün Sınırı Mı?. Ankara: Karadeniz Dergi Yayınları.

AŞKAROĞLU, Vedi. (2015b). Postmodern Söylem: İhsan Oktay Anar ve John Fowles. Ankara: Karadeniz Dergi Yayınları.

AŞKAROĞLU, Vedi. (2012). "Günümüz Sıradan İnsanının Trajik Olgusu ve "KİTABE-İ SENG-İ MEZAR" Şiirinde Süleyman Efendi Betimlemesinde Durumun İrdelenmesi." Dergi Karadeniz, 16.16, ss. 155-164.

AYTMATOV, Cengiz. (2014). Elveda Gülsarı. İstanbul: ÖtükenYayınları.

BACHELARD, Gaston. (1996). Mekanın Poetikası. (Çev. Aykut Derman). İstanbul: Kesit Yayıncilık.

ERDOĞAN, Türkan. (2005). "Reşat Nuri Güntekin'in "Yaprak Dökümü” Adlı Romanında Değişmenin Sosyo-Kültürel Boyutları", Sosyoloji Konferansları Dergisi, Sayı 31.

GASSET, Ortega Y. (1995). İnsan ve Herkes. (Çev. Neyriye Gül Işık). İstanbul: Ayrıntı Yayınları.

GIDDENS, Anthony. (2014). Modernliğin Sonuçları. İstanbul: Ayrıntı Yayınları.

GÜNTEKINN, Reşat Nuri. (2014). Yaprak Dökümü. İstanbul: İnkılap Yayınları. 
İLTER, Tuğrul. (2006). "Modernizm, Postmodernizm, Postkolonyalizm: Ben-Öteki İlişkileri ve Etnosantrizm". Küresel İletişim Dergisi, S.1, Bahar.

KANTER, Fatih. (2009). "Yaprak Dökümü Romanında Yap1 ve İzlek", Turkish Studies International Periodical For the Languages, Literature and History of Turkish or Turkic, Volume 4/8.

KARACA, Şahika. (2013). "Modernleşme Dönemi Türk Romanında Evden Kaçan ve Eve Sığınan Kadınlar", Turkish Studies - International Periodical For The Languages, Literature and History of Turkish or Turkic, Volume 8/1 Winter, p.1817- 1827, ANKARATURKEY.

KARADUMAN, Sibel. (2010). "Modernizimden Postmodernizme Kimliğin Yapısal Dönüşümü", Journal of Yasar University, 17(5) 2886-2899.

KOLCU, Ali İhsan. (2008). Cengiz Aytmatov Üzerine Yazlar. Erzurum: Salkımsöğüt Yayınevi.

KORKMAZ, Ramazan. (2014). Aytmatov Anlatılarında Ötekileşme Sorunu ve Dönüş İzlekleri. Ankara: Grafiker Yayınları.

KORKMAZ, Ramazan. (2015). Yazınsal Okumalar. İstanbul: Kesit Yayınları.

ÖZDEMIR, Gülen. (2009). "Türk Kadınının Toplumsal Konumunun Gelişim Süreci", Namık Kemal Üniversitesi Sosyal Bilimler Enstitüsü, Sosyal Bilimler Metinleri.

SÖYLEMEZ, Orhan. (2009). "Aytmatov’un Aşkları ve Kadın Kahramanları", Kardeş Kalemler Aylık Avrasya Edebiyat Dergisi, Haziran.

SÖYLEMEZ, Orhan. (2010). Cengiz Aytmatov: Tematik İncelemeler. Ankara: Atatürk Kültür Merkezi Yayınları.

ŞENEL, Alâeddin. (2004). Siyasal Düşünceler Tarihi. Ankara: Bilim ve Sanat Yayınları.

UÇAN, Hilmi. (2009). "Modernizm/Postmodernizm ve J.Derrida'nın Yapısökümcü Okuma ve Anlamlandırma Önerisi", Turkish Studies International Periodical For the Languages, Literature and History of Turkish or Turkic Volume 4/8 Fall.

YILMAZ, Dr. Nurullah. (2003). "Nil'in Üç Çocuğu ile Yaprak Dökümü Romanlarında İşlenen Ortak Motifler", AÜ, Türkiyat Araştırmaları Enstitüsü Dergisi, Sayı 21, Erzurum.

YÜREK, Hasan. (2008). "Türk Romanında Modernist Etkinin Boyutları". GÜ, Gazi Ĕgitim Fakültesi Dergisi, Cilt: 28, Sayı:1, 187-202. 